\title{
Educating and integrating minorities: the added value of the school library
}

\author{
Trine Hauger \\ principal \\ Gry Enger \\ teacher-librarian \\ Vahl Primary School, Oslo, Norway
}

\begin{abstract}
Vahl primary school in Oslo is Norway's most multicultural school. 96\% of the school's 300 pupils belong to a linguistic minority (Vaagan \& Enger 2004). The school library is seen and used as an extension of the class room. The range of library activities represent added value in relation to educating minority pupils and assisting in their subsequent integration in society. Some typical minority pupils are discussed, emphasizing in each case how the added value of the library comes into play (1).
\end{abstract}

\section{Introduction}

Norway is becoming increasingly multicultural, and nowhere is this more evident than in the capital Oslo where 35 per cent of all pupils in primary and secondary school belong to a linguistic minority. The paper discusses the school library at Vahl primary school in Oslo, which is Norway's most multicultural school. 96\% of the school's 300 pupils belong to a linguistic minority. 25 languages are spoken at Vahl where Urdu, Arabic, Turkish and Somali are the main languages. The school has 31 teachers, including 5 native speakers in the main non-Norwegian languages. Activities at Vahl primary school library are of considerable interest to professional practice in Norway and internationally. The school was for instance in 2005 elected as one of only 2 "best practice" schools in Oslo. In reading tests in November $2005,7^{\text {th }}$ grade pupils at Vahl primary school scored well above the Oslo school average. The school and the library are regularly visited by school administrators, students and pupils from Norway and abroad (Vaagan \& Enger 2004).

The school library covers an area of 125 square meters and is located on the top floor of our old and venerable school building dating back to 1897. The library is seen and used as an extension of the class room. The teacher-librarian ensures that a broad range of library activities improve language acquisition and development and develop enthusiasm and interest among the children. There is growing understanding in Norway of the importance of the school library, and research has shown that language proficiency is the key to social integration and later to the labour market (Eskeland 2006, Ingvaldsen 2006, Søgnen 2005). The paper discusses how different pupil profiles, reflecting current Norwegian society and the multicultural character of Oslo, can benefit from active school library participation. Typical and intensive case sampling (Patton 2002) of 9 anonymized pupil profiles are presented - 3 individuals and 2 groups with 3 in each. All were born in Norway, are Norwegian citizens, some use the library more than others, but they nonetheless reflect different stages and aspects 
of language proficiency and social integration. In various ways, they all embody the added value gained through school library activities.

\section{The added value of the school library}

As reflected in the IFLA/UNESCO school library manifesto and the excellent IASL website (IASL 2006), there are numerous ways in which the school library offers added value in terms of education, literacy and integration. In this brief article we do not intend to repeat or list the broad range of school library activities that are all potentially relevant for our discussion, and which are familiar to all of you. Our intention is rather to bring to you some concrete glimpses from our particular school library, and highlight how some selected activities offer added value to typical minority pupils. Some IASL delegates visited Vahl primary school last August during the IFLA2005 conference, and these are already familiar with our school library (Enger 2005). The following activities will be highlighted:

- Promoting joy of reading, curiosity and language acquisition Pupils are attracted to the library not least due to the availability of books, storytelling, dolls, puppet theatre, puzzles, reading competitions, games, toys. The teacher-librarian is also seen by many pupils as someone they can confide in and ask questions of various kinds.

- $\quad$ ICT and computer-aided learning

The library is amply equipped with computers connected to the Internet, software, scanners, printers, and cameras which are all eagerly used - in controlled forms (cf. Sundt 2005).

- Pupils’ elected council

The library is also the venue of the Pupils' elected council. This is an important representative body where pupils make their first experiences in elective democracy. The leader of the council sits on the school board and council members are involved in the school's public relations activities

- Inhouse printing press

At Vahl pupils are encouraged to learn to write in their mother tongue before they can read. Many pupils have published their own books through our inhouse printing press "The Reading Company". Vahl uses a technique called "The Writing, Reading and Learning Ladder”.

- Working as library assistants (3 types of jobs)

Pupils in the 5-6 grades can apply for "jobs" as library assistants, either "book police" who transport books and recover missing or overdue books, or "data assistants" who help in all kinds of computer-aided activity, or library assistants who help in general administration.

- Story telling group sessions

This is used to introduce pupils to literature and expand language vocabulary. Story telling in groups, often in parallel sessions e.g. Norwegian-Somali, are very popular. 
- Tranquil retreat

Many pupils consider the library as the heart of the school, a sanctuary where they can escape from the "war zone" outside in the bustling morning corridors.

Of course we could also have included other activities and items, such as the use of theatre performances, the use of puppets and teddy bears during the story telling sessions, the use of boxes with concrete objects linked with the lives and writings of selected authors, or the use of teaching material to measure reading comprehension. Had we done this we would have exceeded the limits of the article.

The stories we have selected are those of Amina, Sadjad, Busra, Omar, Ali, Bilal, Shivali, Derya and Maria. We present them in narrative prose, as miniature life stories.

\section{The story of Amina}

Amina (13) has Pakistani parents. She was born in Norway and is the youngest of 11 children. Her parents are well respected Muslims, who own several textile boutiques in the neighbourhood. Amina speaks Norwegian quite well, though not fluently. She was a shy but very agreeable and clever pupil with considerable ambition and wanted to become a doctor. Her parents didn't have time to help her with home work, her mother does not speak Norwegian and spends most of her time in one of the family boutiques. An elder sister with her own small children had the primary responsibility for Amina. We soon realized that Amina never got involved in conflicts and that her considerable integrity earned the respect and friendship of many other pupils. She obviously liked being in the school library ${ }_{2}$ and when the jobs as library assistants were announced, she quickly responded with an application. Since she was an avid computer user, she signed up for one of the two vacancies as library data assistants. She was a person the teacher-librarian trusted and it was never a problem leaving her in charge of the library during class room visits and absences. Since she was so diligent, her teacher had no objections allowing Amina to frequent the library and seek out challenges she found there. Amina was allowed to work in the library with things she liked and this allowed her teacher to spend more time on other pupils. She thrived when taking on responsibility for a broad range of tasks, answering the phone, assisting in lending out books and other chores for the teacher-librarian and the teachers. With her calm and natural authority she eventually was elected into the Pupils' Council, as chairperson. In this capacity and representing the pupils in different contexts, Amina learned to address audiences, give speeches and be lucid. In the beginning the teacher-librarian pushed her and helped her with oral and written presentations especially speed, variation and lucidity. She was proud that she dared to appear in front of others, and that her classmates applauded her. She had a tendency, which is usual among our Muslim girl pupils, not to answer when asked what they would like to choose between, but eventually she traversed even this hurdle. The collective family identity probably intimidates female family members into silence, few dare stand out in this neighbourhood! Yet in other types of oral presentation such as storytelling for younger pupils, Amina was reluctant to participate. Nonetheless, she loved listening to others telling stories! During her last year at Vahl Amina read a lot, and was in the school library daily both before, during and after school hours. Her incredible curiosity impressed us, as did her yearning for knowledge and her ambition to get on top of things. In recognition of her contributions, she was allowed to take part in the selection of new books and materials for the school library.

When we developed the project "Enjoyable reading 1" for the youngest pupils, Amina helped reading through the books we had chosen. In addition she helped formulate web-based 
questions and answers. As data assistant she was given many time consuming tasks, including scanning texts and images for many of the teachers for their web-based teaching material. Amina also became the most talented pupil of Vahl in sound recording which she had learned from our data teacher. In this way she proved invaluable when we made sound recordings for our Powerpoint presentations. Working on sound recordings and Powerpoint presentations in the library attracted a lot of attention, and Amina was regularly surrounded by younger admirers. Amina also helped locate and download images from the web. These are used to visualize difficult words and concepts, which are explained prior to the story telling sessions. The downloaded images are laminated, which makes them last longer. Later, they are used in class by teachers. After some storytelling sessions we sometimes dramatise the story in order to give the pupils a deeper content understanding. The pupils are allowed to "do" the words, i.e. express them orally and with the body. Amina was entrusted with the documenting a folk tale performance where she wrote a log and used a Powerpoint presentation. She chose someone to handle the digital camera, and she herself did the sound recording and video filming. All this - pictures, video film and sounds - were then mounted in a Powerpoint presentation in one of the library computers. The texts were scrupulously formatted and the end product was greatly admired by younger pupils who became very motivated to learn the trade! We have profound faith in relying on pupils as role models for the younger children. Otherwise when it came to writing Amina did not feel a need to write and publish material through our inhouse printing press "The Reading Company". Amina was extremely proud when she accompanied the teacher-librarian to Trondheim 1 hour by plane north of Oslo, and assisted Gry Enger when she gave a lecture to an audience of 1,000 people, and even expressed a few words The girl virtually grew in stature when many conference participants complimented her the following day. To Amina the school library became not only a place to locate literature and information. The library perhaps more than anything was about enjoyment and dialogue, a place where she could thrive and develop skills, somewhere she could gain confidence by being elected to and fulfilling the duties of the Pupil's Council. Now she attends the local junior college nearby Vahl primary school, and she has again been elected to the new school's Pupils' Council. She still drops in for a chat, to borrow a book and check out developments especially regarding our data equipment. We think she may well become a medical doctor!

\section{The story of Sadjad}

Sadjad (12) is a gifted boy of mixed parentage, with a Norwegian mother converted to Islam, and an Iraqi father. The parents are now divorced. The father who is a medical doctor, lives in the residential and affluent western side of Oslo whereas the mother has decided to settle in less affluent eastern parts of Oslo with a new Muslim husband. This means that Sadjad does not live in the neighbourhood of the school in contrast with most of his classmates. He also alternates between spending one week with the father and another with his mother. He feels very torn between his converted mother's attraction to Islamic fundamentalism and his father's wish to Westernize and integrate. He is a strikingly handsome and sensitive boy and he speaks Norwegian fluently. He started at Vahl primary school two years ago and his class then was well established. The teachers saw a well behaved boy, neat and clean in his clothing, with a perfect Norwegian, diligent and clever at school and sociable. The girls were all in admiration while the boys were more reserved. He experienced a difficult time to begin with, and easily cried. An announcement of library vacancies had just been published and he was encouraged to apply. He did, and signed up to become one of the school's two new "book police" library assistants. The two went all over the school with their trolley, transported books between office and library, demanded overdue 
books from teachers and pupils. This made them popular, but the tough guys were still not convinced they wanted to accept the newcomer....who was so agreeable and accommodating. He often came to the library to borrow books, and was allowed to tale part in the acquisition of new books for the library. The teacher-librarian has a way of getting to know what kind of books the children like for story telling sessions in the library. Sadjad preferred stories about animals, which is not quite so usual among action-oriented boys. As the summer holidays drew nearer his group took part in the "Enjoyable reading 2" project for the older pupils. Sadjad started out very eagerly, but he lost interest somewhere along, possibly because the questions he got were too easy, and possibly also due to hormonal changes and adolescence. It was rumoured that some of the tough boys called him sissy. Sadjad never handed in any manuscript to the "Reading Company". But perhaps something will materialize next year? Nor was he elected to the Pupils' Council. But due to his insecurity this was perhaps understandable. When guests from IFLA visited Vahl primary school and the library in August 2005 as part of the excursion programme, and some of you are here today, you were shown our first animation film - The Lion and the mouse " one of Aesop's fables. It was decidedly not succesful, although perhaps it may have been entertaining due to its obvious lack of technical knowledge. But the children loved working on this project and we completed it during the summer recess. For some time the teacher-librarian had been pondering how to expand the use of ICT and computers from literature to other fields and subjects. Could e.g. Google Earth be used in teaching geography? When two of our teachers had the possibility to specialize in animation techniques, the teacher-librarian suggested focussing on the subject Christianity and world view (KRL). Noah's Ark was chosen and 16 pupils were selected, including Sadjad. At this point he did not come so often to the library as before, and was no longer a "book police" library assistant. He had changed, and had now taken on a rather impudent attitude, always trotting behind the toughest boys. Perhaps this development was predictable? A rather small and exclusive group of $6^{\text {th }}$ graders were asked to work 2 weeks on the Noah's Ark project. After a fumbling start, the process gained momentum. Hard and concentrated work was essential with plastelina, but what a good time and great laughs we all had! The teachers learned so much about pupil participation and involvement, and it struck us that the boys were probably most excited and concentrated in this project. Some managed to stay focussed for 4 hours, although this ought not to be an objective. Sadjad astounded everyone with his tenacity and engagement. When we had to record sounds, he was the first to learn the technique, not the teacher-librarian. He worked away from his tough "friend", and was praised by the professional teacher of animation techniques. With his creative and technical abilities Sadjad was quickly chosen as a replacement for one of our two data assistants who had just left school . One of the animation boxes will remain in the library awaiting new productions. Sadjad achieved recognition and felt he had managed to master a technique. We sincerely hope this will influence him to go ahead and explore new uncharted waters! His teacher was very pleased that Sadjad had shown involvement and joy in the Noah's Ark project, and as data assistant he will be offered many challenges ahead in the school library.

\section{The story of Busra}

The family of Busra (11) originate in Turkey. Her father is unemployed and speaks some Norwegian , the mother is illiterate and her Norwegian is rudimentary. Busra's father and mother are cousins. Busra is one of five children. The silent pupils are easily overlooked, and although Busra is taller than her classmates she easily disappears once activity and noise increase since more forward pupils are often first attended to. Busra is slow in most things, also apparently her reflection. We have many pupils who reflect a similar kind of indolency 
in this part of Oslo where intermarriage is frequent. Busra keeps a very low profile, and often appears to be absentminded. Her Norwegian is poor and she always sticks to her Turkish girl friends. One morning she was standing outside her class room as the teacher-librarian was passing and a noisy gang of boys were approaching. The teacher-librarian paused and asked if Busra wanted to help her with some books. In this way she evaded the "war zone". In the corridor outside the library there is a table, chairs and a couch, and this has turned out to be a favourite refuge for silent pupils in the morning before class begins. The teacher-librarian often allows them into the library. This is also the time when the youngest pupils make their way up the four flights of stairs to the library with their "Easy-to-read-books", proud to have finished reading them, and it is a must to receive these satisfied customers! Busra is allowed in , at first she used to say little, she usually occupied herself with a puzzle and just looked at the teacher-librarian going about her chores. We have books in Turkish, but she cannot read Turkish, and in fact she rarely reads anything. Nonetheless, she often remained sitting, leafing through the Turkish picture books. From time to time Busra took home some of the books in Turkish, so she could consult her family and report back what the books were about. Busra has always been proud that she has managed to fulfill this task. The teacher-librarian has often paid Friday visits to her pupils but has yet to see any book shelves in their homes. The only visible book is the Koran. At times it can be challenging to witness this type of cultural gap. The teacher-librarian has given Busra challenges in language and communication games , and has tried to explore what Busra needs in terms of concepts and words. Gradually, Busra has come round to talking more, and she has now taken on the task of sorting out the hand dolls and our teddy bear assistants "Winnie the Pooh and his family". Busra's mother has visited the library, and her fantastic speed in knitting has allowed her to dress many teddy bears in wonderful new knitted clothing. This has given Busra a sense of belonging and security combined with positive attention from the younger pupils. It is this kind of experience that makes our day at Vahl. Busra has also taken part in the 6th grade "Enjoyable reading 2 " project for the older pupils, and she is eager at taking notes on difficult words in her little notebook. In the safer context of the library, Busra can then in a smaller group setting, safely ask and enquire about difficult words. Here her narrow vocabulary is not so noticeable. But her reading is slow, and she continues to have problems, although she scored well on her efforts. At least she had taken part and tried, like all the rest! Busra is the kind of pupil whom one easily gives insufficient attention, although she requires continuous input. She is precisely the kind of pupil who can benefit from an alternative or extended classroom - the library. Busra was never elected to the Pupils' Council , she is too passive and withdrawn for that. Nor has she ever published anything through "The Reading Company". On the other hand she greatly enjoyed all the story telling group sessions, and particularly enjoyed hearing about princesses. She still has not applied for a job as library assistant, and that is perhaps for the best, since this may well be too much for her. She has rarely used the computers. Busra has therefore first and foremost benefited from the library as an alternative, extended class room, a refuge where she can work in peace. Here she has been allowed to work on the Norwegian language in a different and more individually adapted manner, which she has enjoyed.

\section{The stories of Omar, Ali and Bilal}

All schools have fidgety pupils and rogues, some of whom at times come close to (or step over) limits of acceptable behaviour._Omar (12), Ali (13) and Bilal (13) from Pakistan, Lebanon and Iran, respectively, were in the 4th grade when the following incident took place in the library They had arrived with their teacher and a group of roughly 20 boys and girls for a session of individual quiet reading. The teacher-librarian sensed after a while that the three 
boys somehow were missing. She quietly walked around, went out into the hall, but the rogues had simply disappeared. The she discovered them tucked away in a corner concealed behind a couch and immersed in the book "Find Willy". They told her the corner was such a cool place to be. The teacher-librarian is always in search of new possibilities with a teaching potential and immediately pondered how this situation could be used. Could the 3 boys be positively motivated into arranging that particular corner? The four quickly agreed that a special boys' corner could be constructed, hence called "the Secret Corner". Paper and pencils were laid out on the table and drawings set up! Who should do what? Two of them had to ask the principal for permission and were sent of to market the plans. Could they go ahead and buy some paint? Was it OK to get tarpaulin, cloth from the handicraft teacher to make a set of paravans? The school janitor shaped a wooden framework. Handouts were distributed to inform other pupils that the three had set up and annexed "The Secret Corner"! A father contributed hammer and nails, and the teacher-librarian had to hastily bring in her staple gun. The tarpaulin was stretched to fit the wooden frames, and then painted and decorated with red roses. For a couple of weeks the three boys arrived an hour before classes started in order to work on their project, they dressed up in working clothes and showed great motivation and inspiration! Some small accidents with hammers and nails that resulted in a sore thumb or scratch were brushed aside. This whole project was a demonstration of Dewey's principle of "Learning by doing" The three boys quickly developed a vocabulary of Norwegian terms for practical work. Bilal learned to sew, he positioned himself cross-legged on a table like a professional tailor and produced three cushions in no time at all. These three charming rogues had acquired focus and motivation and created something that benefited everyone. From the outset they were not prone to reading, and neither was their Norwegian very impressive. But this project released a lot of positive energy and meaning. They were continuously in the library to pursue their project. Once they paravans were up and the cushions laid out, and sufficient reading light in place, the three boys decorated and improved on all the details. Their reading also picked up as the project materialized, they played chess and doted over their Secret Corner. A small story regarding this particular corner is relevant at this point. Our school was some years ago in danger of being closed due to financial restrictions in the city budget. We organized petitions against the planned closure and visited the city council to voice our protests. During a meeting with local politicians Omar stood up and told them that they couldn't close down Vahl primary school, for what would then happen to the Secret Corner? Omar, Ali and Bilal spent another 3 years at Vahl primary school, and continued to dote over their pet project. Two of them in fact turned out to among the most avid readers and went on to assist the teacher-librarian in book selection and acquisitions. Omar, the leader of the three, was later elected onto the Pupil's Council. All three used computers from time to time but none of them became library assistants. Perhaps they were too fidgety for this type of library work. But they all enjoyed greatly our story telling sessions. And Omar, the leader, is today a very motivated and well integrated pupil in a one of the capital's best junior college, in another part of town. Perhaps the Secret Corner project coincided with a crucial point in these boys' development and had a decisive impact on their development. Perhaps the varied activities of the school library have positive and long term effects on our pupils. We would like to think so. It is important to be receptive to the needs of the pupils and try and channel their interests into feasible projects and activities that are within our limits and means. Today a younger sister of Omar has taken on the responsibility of looking after The Secret Corner. A new group of $4^{\text {th }}$ grade girls are now busily engaged in developing a similar project in another corner of the library. The teacher-librarian is willing to be flexible as long as the end result are happy and confident library users ! 
Finally, I would like to present our "3 busy and merry mini mothers" Shivali (10), Derya (10 ) og Maria (10 ). They originate in India, Turkey and Pakistan . Their parents are open and friendly, and they each have 2-3 brothers and sisters. They all speak quite good Norwegian, but with a limited vocabulary in Norwegian which is common with pupils at Vahl primary school. They stick closely together, they are at the same class level but in different groups. They are all diligent, accommodating, well-behaved and have a positive and extrovert attitude to life in general. They are strong-willed girls continuously searching for new possibilities. This type of pupil needs alternative arenas as an outlet for their surplus energy, creativity and curiosity. Fortunately most of our teachers have realized this, and let the 3 off once they have fulfilled their duties to pursue other challenges. The 3 simply love the school library. Their only objection is whenever the teacher-librarians is absent, which they take as an insult! The 3 have almost moved into the library. As told earlier, the boys had made a Secret Corner. This proved to be unacceptable to the 3 girls. For some time they have therefore decorated a separate "room" behind one of the corner couches. They have stretched material between the couch and the walls and installed themselves with various items. They keep their "room" very neat, they regularly turn up before school starts in the morning to deliver sundry "important" items, and they regularly stay behind after school hours. On the outside of their corner room they have written small laminated "No entrance" signs, with accompanying details of what will happen to offenders. Two of the girls are book assistants and the third is on a waiting list. Vahl primary school is into its third year as a "visiting school", and has over the last two years received many visitors and delegations from other parts of Oslo and Norway. Many visitors want to be shown around the library, and the young assistants proudly guide visitors together with the teacher-librarian. To these three girls the library represents both serious working and enjoyment. They know the teacher-librarian expects and demands that they help, and they take their jobs very seriously. They are invaluable to the library and their delightful presence is a great asset. They have become experts in handling the lending machines, and prove themselves extremely useful when many pupils suddenly turn up in the library and need to be serviced. Here they also assist in locating relevant literature, and do not stop short of scolding when necessary. They also teach the youngest pupils how to handle books and find books on the shelves. This is also a precondition for receiving the "yellow tiger card". When the youngest pupils have received this, they are allowed to borrow books and take them to their class rooms. The 3 girls also assist the teacher-librarian in fitting the books with markers and bar codes, stamping books and keeping the shelves tidy. When the teacher-librarian needs to leave the library, the three girls willingly step in as temporary replacements, answering the phone and learning to accept responsibility. Maria is member of the Pupils' Council 2005-2006, and the two others have previously been elected members. The three are also very interested in acting as "teacher" and are now taking actively part in the "Enjoyable reading 1" project helping younger pupils. All three took part in this last year when and are now able to actively assist the teacher-librarian. Now they are looking forward to next year when we plan to start the follow-up "Enjoyable reading 2" for the older pupil. Then they hope to do even better because they want to be among the six pupils who are chosen to visit the teacher-librarian's mountain resort. Our hand dolls have been a great source of inspiration for these three girls in the past. They used to set up small puppet shows for the younger pupils and for the little special class with five pupils. The three have always valued the teacher-librarian's story telling sessions, and these days they particularly enjoy suspense stories. They know that the teacher-librarian, before starting the story, explains difficult words and concepts. These are often visualized by means of 
laminated images explained before the story telling sessions. The three girls enjoy working on this aspect, and they download suitable words and images from the Internet and laminate them. The pupils are regularly encouraged to propose texts or stories that are suited for story telling sessions. The three girls have gradually acquired a taste for story telling themselves , and these days they often join the teacher-librarian when she visits classes with smaller children accompanied by the teddy bear "Winnie the Pooh". Small wonder these girls spread so much joy around! They are also instrumental in recruiting new library users, since they do enjoy certain advantages. Among other things they are allowed to be more often than other pupils in the library, and they can borrow more books. Shivali, Derya and Maria are involved in all the activities of the library, but with one exception: they have not presented their own manuscripts for publishing by the Reading Company. But this may also be because they are so involved in all other library activities.

\section{Summary}

As we have seen the added value of the school library at Vahl primary school is a function of services and activities connected with a) promoting joy of reading, curiosity and language acquisition; b) ICT and computer-aided learning; c) the Pupils' Elected Council; d) the inhouse printing press; d) working as library assistants; e) story telling group sessions and f) a place of tranquil retreat. These services and activities have served to give added value to children such as Amina, Sadjad, Busra, Omar, Ali, Bilal, Shivali, Derya and Maria. As the stories of these pupils reflect, working in the school library has given all these minority children in various ways a better education, heightened literacy, improved language acquisition and a better position in terms of social integration.

\section{Conclusion}

On the basis of the outlined school library activities and the typical and intensive sampling of pupils, we can conclude that the library at Vahl Primary school represents added value with regard to educating and integrating minority children.

\section{References}

Enger, G. (2005). “The school library at Vahl primary school” (Lecture given to IFLA delegates visiting Vahl primary school 16 -17 August 2005, during the excursion program of the $71^{\text {st }}$ IFLA General Conference and Council. (unpublished manuscript).

Eskeland, T. (2006). ”Vil ha egen Stortingsmelding om skolebibliotekene”, Bibliotekforum 1 (06) 14-15

International Association of School Librarianship (2006). School libraries online. Viewed 25 March 2006 at: http://www.iasl-slo.org/

Ingvaldsen, S. (2006). ”Skolebibliotekene og Kunnskapsløftet”, Bibliotekforum 1 (06) 6-7

Patton, M.Q. (2002). Qualitative Research \& Evaluation Methods. London: Sage

Sundt, E. (2005). “Make Space for Reading!” The Norwegian Strategy for Stimulating Love of Reading and Reading Skills, 2003-2007. Lecture given during IFLA2005, Oslo 14-18 August 2005. Viewed 28 March 2006 at: http://www.iasl-slo-org/ifla2005-sundt.html

Søgnen, A. (2005). Idéhefte. Oasen i skolebygget. Skolebiblioteket som læerings- og informasjonssenter. Oslo:Utdanningsetaten 
Vaagan, R. \& Enger Gry (2004). "Developing the multicultural school library: Vahl primary school, Oslo". New Library World, 105, (1204/1205), 2004, 337-344

Vahl primary school (2006). Viewed 28 March 2006 at: http://www.vahl.gs.oslo.no/

\section{Author note:}

Trine Hauger, BA, has been the principal of Vahl Primary School since 1997. She has taught in multicultural schools for ten years and has been a school principal the last eleven years. Trained as teacher with media, school library and management as subjects, her major interest is learning abilities in multicultural schools.

Gry Enger, BA, is a graduate of The State Drama School, and later completed a university degree in religion. She worked 15 years in drama before coming to teaching. For 4 years she assisted in visualizing the teaching of Norwegian to children in a Muslim preparatory school in Oslo, before joining Vahl primary school as teacher-librarian 6 years ago.

(1) We would like to thank Dr. Robert Vaagan, Faculty of Journalism, Library and Information Science, Oslo University College, for his kind assistance with this article. 
Reproduced with permission of the copyright owner. Further reproduction prohibited without permission. 